\title{
TECCIENCIA
}

\section{Design and construction of a solar collector parabolic dish for rural zones in Colombia}

\section{Diseño y construcción de un colector solar parabólico tipo disco para zonas rurales en Colombia}

\author{
Jorge Alexander Alarcón ${ }^{1}$, Jairo Eduardo Hortúa ${ }^{2}$, Andrea López $\mathrm{G}^{3}$ \\ ${ }^{1}$ Universidad Distrital Francisco José de Caldas, Bogotá, Colombia, alexander.alarconv@ gmail.com \\ ${ }^{2}$ Universidad Distrital Francisco José de Caldas, Bogotá,Colombia, ing.jairohortua@ gmail.com \\ ${ }^{3}$ Universidad Distrital Francisco José de Caldas, Bogotá, Colombia, andrea_lopgo@ @otmail.com
}

Accepted: 18 June 2013

Published: 30 July 2013

\begin{abstract}
This paper presents the development of a solar parabolic dish collector prototype for rural areas with high solar resource availability in Colombia, which have no access to electricity service or budget resources to purchase a stove (electric or gas). The solar collector prototype proposes a solution to solve these kinds of issues and use sunlight to work it. Through a polished stainless steel parabolic dish, solar radiation is concentrated into a specific area called focus, where thermal energy is generated and is used for cooking or fulfilling a necessity without high investment and helping the environment. To finish, it describes the decisive stages of the prototype implementation, which provides the solar resource analyzed in Colombia, the theoretical analysis, the structural design, the study, and manufacturing materials.
\end{abstract}

Key words: Focus, Heat losses, Solar concentrator, Thermal efficiency, Temperature

\section{Resumen}

Este artículo presenta el desarrollo de un prototipo de colector solar parabólico tipo disco para zonas rurales con gran disponibilidad del recurso solar en Colombia, las cuales no tienen acceso al servicio de energía eléctrica y/o no cuentan con los recursos económicos para adquirir una estufa (eléctrica o a gas). El prototipo planteado como solución a dicha problemática, concentra la radiación solar directa por medio de un disco parabólico de acero inoxidable brillante, en un punto llamado foco, en el cuál se genera energía térmica que puede ser utilizada para la cocción de alimentos, satisfaciendo una necesidad a un bajo costo y contribuyendo al medio ambiente. Posteriormente se exponen las etapas determinantes para la implementación del prototipo, las cuales contemplan el análisis del recurso solar en Colombia, análisis teórico, diseño, estudio de materiales y la fabricación del colector.

Palabras claves: Concentrador solar, Eficiencia térmica, Foco, Pérdidas de calor, Temperatura

\section{Introduction}

Demand for electric energy is on the rise throughout the world; the need for electric and electronic systems increases and is part of modern society; the tendency of global demand reveals that the emerging economies will begin to require more and more electricity, given their exponential growth. Increased greenhouse gases like carbon dioxide ( $\mathrm{CO} 2)$, sulfur dioxide ( $\mathrm{SO} 2)$, and nitrous oxide (NOx), which aside from

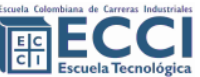

contaminating the environment also bring devastating consequences for climate change, show us that our dependence on current finite fossil fuels (oil, coal, natural gas, and other oil derivates), and that they are not the only alternative for energy production. Stemming from this problem, we must embark on a continuous search for new inexhaustible energy sources.

The sun, as the main source of light and heat for

How to cite: Alarcón, J; Hortúa, J.:López, A. Design and construction of a solar collector parabolic dish for rural zones in Colombia, TECCIENCIA, Vol. 7 No. 14., 14-22, 2013, DOI: http:/dx.doi.org/10.18180/tecciencia.2013.14.2 


\section{TECCIENCLA}

the earth, is considered an inexhaustible energy source of easy access, free, clean, and renewable. Consequently, and view of Colombia's geographic location (lack of seasons), the country has great availability of the solar resource. Privileged zones like la Guajira, the Atlantic Coast, and Orinoquía are the starting points for the development of thermal solar energy.

Projects have been conducted in the country with photovoltaic technology. These have contributed to its energetic growth; however, few studies and projects have helped in the development of thermo-solar technology. Due to this, the search was begun for an energetic solution applied to using the solar resource for thermal purposes, finding that collector systems represent a competitive option for energy conversion and generation.

\subsection{Analysis of the solar resource in Colombia}

Knowing the solar potential Colombia has is an indispensable factor for the development of solar and thermo- solar technologies, given that the exploitation of the natural resource and its efficient use aimed at the country's energy development and efficiency depends on this knowledge.

For this purpose, it is important to know the amount of solar energy that impacts upon the country's terrestrial surface, as well as its geographic advantages that favor the availability of the solar resource. This work has been developed by state entities like Energy Mining Planning Unit (UPME) (1) and IDEAM (Instituto de Hidrología, Meteorología y Estudios Ambientales - Institute for hydrology, meteorology, and environmental studies), through the publication of the atlas of solar radiation, elaborated in 2005, which has an approximation of the spatial distribution of the country's solar resource. Said maps show the monthly and annual average information of global radiation and sunshine per region, among other aspects.

Figure 1 shows the multiannual average of global solar radiation incident on the Colombian territory and the multiannual average of hours of sun per day. Based on the information from Figure 1, we may approximate the multiannual mean availability of solar energy per region, as indicated in Table 1.
Table 1: Mean multiannual availability of solar energy per region. [1].

\begin{tabular}{|c|c|}
\hline Region & $\mathbf{k W h} / \mathbf{m}^{2} / \mathbf{y e a r}$ \\
\hline Guajira & 2190 \\
\hline Atlantic Coast & 1825 \\
\hline Orinoquia & 1643 \\
\hline Amazonía & 1551 \\
\hline Andean & 1643 \\
\hline Pacific Coast & 1278 \\
\hline
\end{tabular}

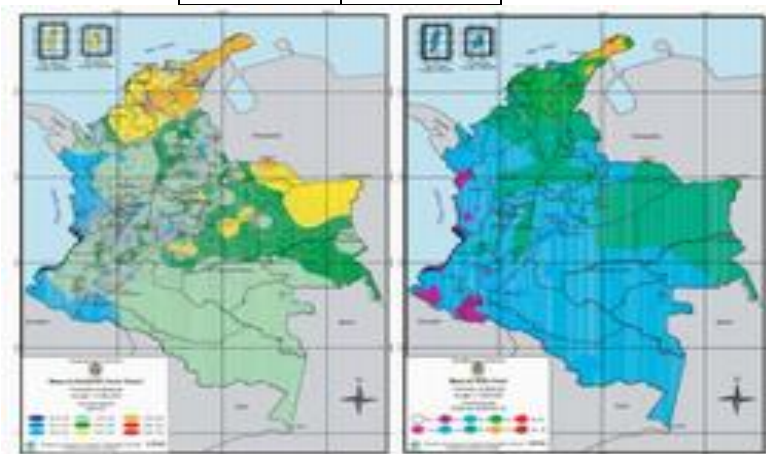

Figure 1: Maps of multiannual average global radiation and sunshine. [1]

According to Figure 1, the departments of la Guajira, Cesar, Arauca, Magdalena, and Atlántico are the adequate sites to implement thermo-solar technologies, given that the multiannual average of solar radiation is between $5.5 \mathrm{kWh} / \mathrm{m}^{2}$ and $6 \mathrm{kWh} / \mathrm{m}^{2}$; in addition to having average sunshine of 6 to $8 \mathrm{~h}$ per day, which guarantees the solar resource during much of the year. Of the departments mentioned, la Guajira is the optimal place for the development of these technologies, given that its average radiation and sunshine is higher with respect to the other regions of the country.

Now, given that the project was developed in Andean region and according to Figure 1, it is noted that the daily mean availability of solar energy is $4.5 \mathrm{kWh} / \mathrm{m}^{2} /$ day. Bogotá has a mean daily radiation of $3.5 \mathrm{kWh} / \mathrm{m}^{2}$ to $4 \mathrm{kWh} / \mathrm{m}^{2}$, and daily sunshine of 3 to $4 \mathrm{~h}$ per day. The aforementioned represented in $\mathrm{W} / \mathrm{m}^{2}$ signifies a daily mean radiation of $1166 \mathrm{~W} / \mathrm{m}^{2}$ and 1000 $\mathrm{W} / \mathrm{m}^{2}$, approximately.

\section{Theoretical analysis of the solar dish concentrator}

\subsection{Prototype Geometry}

The collector's parabola geometry is fundamental to guarantee proper functioning of the prototype; an error during the geometric calculation would represent deviation of the solar 


\section{TECCIENCIA}

rays; consequently, the absence of temperature at the focal point, which would give way to obtaining low thermal efficiency.

To calculate the parabola, a mathematical analysis was performed to find the values that satisfy the design criteria, like: diameter, aperture angle, and concentration ratio. The scheme used for the analysis is shown in Figure 2.

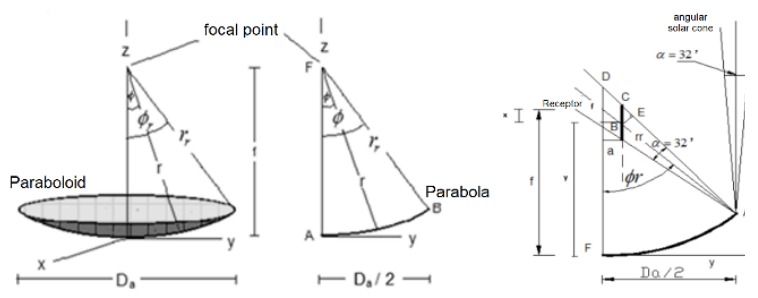

Figure 2: Geometry and dimension of the solar collector parabolic dish

Table 2 presents the dimensions used for the design of the solar collector dish.

Table 2: Dimensions of the solar collector parabolic dish

\begin{tabular}{|c|c|c|}
\hline Nomenclature & Value & Description \\
\hline $\mathrm{Da}$ & 1.5 & Diameter of apertura $(\mathrm{m})$ \\
\hline $\mathrm{F}$ & 0.42 & Focus $(\mathrm{m})$ \\
\hline $\mathrm{A}$ & 0.015 & $\begin{array}{c}\text { Radius of the cylinder } \\
\text { receptor }\end{array}$ \\
\hline
\end{tabular}

The diameter of aperture and the maximum angle that defines it are related by equation (1)

$$
\emptyset=2 \operatorname{arctg} \frac{D a}{4 f}=83.521^{\circ}
$$

Another important parameter to adequately define the geometry of the solar collector parabolic dish is the edge radius (rr) or maximum distance value existing between the focal point and the paraboloid extreme. Equation (2) defines said value as the following:

$$
r r=\frac{2 f}{1+\cos \emptyset}=0,7548 \mathrm{mts}
$$

An indicator to bear in mind in solar collector systems is the concentration index or concentration ratio; the higher the concentration ratio, the higher the temperature to be reached with the solar concentrator system. Parabolic dish collectors are characterized for having a higher concentration ratio than the rest of the solar collector systems. The concentration index is defined as the ratio between the aperture area (Aa) and the area of the receiver (Ar), as shown in equation

$$
C=\frac{A a}{A r}
$$

The aperture area can be calculated through the following ratio:

$$
A a=\frac{\pi D a^{2}}{4}=1.7671 \mathrm{~m}^{2}
$$

To find the area of the receiver, it is necessary to consider the aperture angle, the radius of the receiver, the radius of the edge, and the angle supported by the sun seen from the earth. This last constant is because the rays from the sun are not parallel to each other, given that the sun has a finite radius. From the earth, the sun is seen as a circular dish that subtends a $32^{\prime}$ or $0.53^{\circ} \alpha$ angle. From Figure 2, it is known that $\mathrm{a}=0.015 \mathrm{~m}$, $\mathrm{c}$ is the hypotenuse formed between the focus and point $B$ and $\varnothing=83.521^{\circ}$. According to the aforementioned, we have:

$$
c=\frac{a}{\operatorname{sen} \varnothing}=0,015096429 \mathrm{~m}
$$

Now, point B would be equal to:

$$
b=r r-c=0,739725
$$

Figure 3 shows the geometric ratio of points $\mathrm{ABE}$ and $\mathrm{BCA}$.

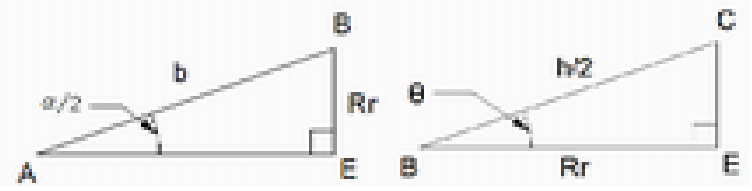

Figure 3: Geometric ratio of points $\mathrm{ABE}$ and BCA

Where $\mathrm{Rr}$ is the receptor radius. According to the previous figure, we obtain:

$$
R r=b \operatorname{sen}\left(\frac{\alpha}{2}\right)=1,72131 \times 10^{-3} \mathrm{~m}
$$

Upon observing Figure 3, the following geometric ratio is noted among points BCE: Where $h / 2$ is half the contact surface of the receiver cylinder. With the equation, we obtain the angle formed between $\mathrm{h} / 2$ and $\mathrm{Rr}$.

$$
\theta=90+\frac{\alpha}{2}
$$

We also find half the contact surface of the receiver cylinder, as noted in equation (9):

$$
\frac{h}{2}=\frac{R r}{\cos (\theta-\varnothing)}=0,00206 \mathrm{~m}
$$

The area of the receiver can be determined through equation (10): 


\section{TECCIENCIA}

$$
A r=2 \pi a h=387.9 \mathrm{~mm}^{2}
$$

With values $\mathrm{Aa}, \mathrm{Rr}$ and applying equation (3), we proceed to calculate the concentration ratio of the solar collector parabolic dish:

$$
C=\frac{1.7671 \mathrm{~m}^{2}}{0,0003879 \mathrm{~m}^{2}}=4555,671
$$

The calculated concentration ratio corresponds to the maximum concentration obtained within a parabolic concentrator with a flat receptor; however, equation 11 does not consider the angular dispersion in the receptor. The main causes of said dispersion are: inappropriate solar monitoring, poor quality in the polish of the reflector surface, and inadequate curvature on the concentrator surface.

Bearing in mind the angular dispersion and considering that all the specular radiation reflected is on an angular cone with $\left(0.53^{\circ}+\delta\right)$; from equation (12), we may find the value of the contact surface of the receiver cylinder considering the angular dispersion:

$$
h 1=\frac{2 R r}{\cos \left(\theta-\varnothing+\frac{\delta}{2}\right)}
$$

Where: $\delta$ is the specular deviation, which has a theoretical value of 3 degrees. Finding the value of $\mathrm{h} 1$, the actual maximum concentration ratio would be defined by equation (13):

$$
C \operatorname{maxr}=\frac{A a}{2 \pi a h 1}=4475,975
$$

With the actual maximum concentration ratio, we can obtain the optimal focal distance (fo), so that the highest possible concentration is achieved. By substituting, we have equation (14):

$$
C=\frac{\frac{\pi D a^{2}}{4}}{2 \pi a h}
$$

Clearing Da in equation (14) and using the actual maximum concentration ratio:

$$
C \max r=\frac{A a}{2 \pi a h 1}=4475,975
$$

For which, by clearing $\mathrm{f}$ in equation (1) and using the value of Da1, we have the optimal focal distance, as noted in the equation:

$$
f o=\frac{D a 1}{4 \operatorname{tang}\left(\frac{\emptyset}{2}\right)}=0,41631 \mathrm{~m}
$$

Thermal and optical calculation
After performing the theoretical analysis for the construction of the solar collector parabolic dish, the following presents its thermal and optical analysis.

The optical efficiency of the collector is given by equation (17):

$$
n_{o}=\rho_{c} \tau_{v} \rho S
$$

Table 3: Necessary values to calculate the optical efficiency

\begin{tabular}{|c|c|c|}
\hline Parameter & Nomenclature & Value \\
\hline Receptor absorptance & $\rho_{c}$ & 0.85 \\
\hline $\begin{array}{c}\text { Transmittance of the glass coating the } \\
\text { (if it exists). In this case, it does not } \\
\text { exist, then it is equal to 1 }\end{array}$ & $\tau_{v}$ & 1 \\
\hline Reflectivity of the concentrator & $\rho$ & 0.572 \\
\hline Shape factor & $\mathrm{S}$ & 0.9996 \\
\hline
\end{tabular}

The shape factor (S) is given by equation (18):

$$
S=\frac{A a-A t}{A a}
$$

Where, At represents the fraction of the concentrator's aperture area, which is not shadowed by the receptor. Equation (19) determines the fraction of the aperture area not shadowed by the receptor.

$$
\begin{array}{r}
A t=\text { Aa-Area base recibidor } \\
=1.7664 \mathrm{~m}^{2}
\end{array}
$$

Upon applying in equation (20), we have that the prototype's optical efficiency is 0.49 .

$$
n_{o}=0.49 * 100=49 \%
$$

With this value, it is possible to find the average temperature in the receiver of the solar collector, as shown in equation (21):

$$
\left.=\frac{\operatorname{Tamb}+\operatorname{Tsol} *\left[(1-n) * \frac{n_{o} * C \max }{46311 * \varepsilon}\right.}{2}\right)
$$

Where:

Table 4: Necessary values to calculate temperature in the receiver

\begin{tabular}{|c|c|c|}
\hline Parameter & Nomenclature & Value [Unit] \\
\hline Environmental temperature & Tamb & $\begin{array}{c}20\left[{ }^{\circ} \mathrm{C}\right] \text { or } \\
293.16[\mathrm{~K}]\end{array}$ \\
\hline $\begin{array}{c}\text { Approximate temperature of } \\
\text { the sun }\end{array}$ & Tsol & $\begin{array}{c}5726.84\left[{ }^{\circ} \mathrm{C}\right] \\
\text { or } 6000[\mathrm{~K}]\end{array}$ \\
\hline $\begin{array}{c}\text { Emissivity del receiver } \\
\varepsilon_{r}\end{array}$ & 0.5 \\
\hline
\end{tabular}




\section{TECCIENCIA}

Maximum efficiency range of

solar collectors $(40 \%-60 \%)$

To calculate the average temperature in the receiver, efficiency was estimated at $0.4,(2,3)$ given that the maximum efficiency range in these collectors is between 0.4 and 0.6. Upon applying the values presented in Table 4, in equation (21) we have that:

Table 5: Average temperature in the receiver

\begin{tabular}{|l|l|}
\hline Trm & $161.97^{\circ} \mathrm{C}$ \\
\hline Trm & $435.13 \mathrm{~K}$ \\
\hline
\end{tabular}

The direct radiation measured in the area of Chapinero in Bogotá is $826.68 \mathrm{~W} / \mathrm{m} 2$. With this radiation it is possible to estimate the energy absorbed by the receptor through the following equation:

$$
Q_{o p t}=A a \rho_{c} \tau_{v} \rho S I_{b}=710 \mathrm{~W}
$$

Where Aa is the aperture area, $\rho c$ is the receptor absorptance, $\tau \mathrm{V}$ is the transmittance, $\mathrm{S}$ is the shape factor, and eIb is the mean direct radiation. Now, to learn of the useful energy in the receiver, we must calculate the receiver's energy loses to the environment, which are given by equation:

$$
Q_{\text {loss }}=A r U_{L}(\operatorname{Trm}-T a m b)
$$

Where $U_{t}$ is the $\mathrm{m}$ / ean coefficient of heat losses, which is represented by:

$$
\begin{aligned}
& U_{L}=\left[\frac{1}{h_{w}+h_{r}}\right]^{-1} \\
& =19.85 \mathrm{~W} / \mathrm{m}^{2} * K
\end{aligned}
$$

The terms hw and $\mathrm{hr}$ correspond to the convection coefficient and radiation coefficient, respectively. The radiation coefficient is given by:

$$
h_{r}=4 \sigma \varepsilon_{r} \text { Tair }^{3}=2.84 \frac{W}{m^{2}} * K
$$

Where:

Table 6: Variables employed to calculate the radiation coefficient

\begin{tabular}{|c|c|c|}
\hline Variable employed [Unit] & Nomenclature & Value \\
\hline $\begin{array}{c}\text { Stephan-Boltzmann } \\
\text { constant[W/m2*K4] }\end{array}$ & $5.67 * 10-8$ \\
\hline $\begin{array}{c}\text { Average air temperature in } \\
\text { Bogotá in }\left[{ }^{\circ} \mathrm{C}\right]\end{array}$ & Tair & 19.5 \\
\hline $\begin{array}{c}\text { Average air temperature in } \\
\text { Bogotá in }[\mathrm{K}]\end{array}$ & Tair & 292.7 \\
\hline
\end{tabular}

To calculate the convection coefficient, we consider the thermal conductivity of air (kair), the receiver diameter (Dout), and the Nusselt number $(\mathrm{Nu})$, which must be calculated from the Reynolds number (Re).

$$
h_{w}=\frac{k_{\text {air }}}{D_{\text {out }}} * N u
$$

The Reynolds number is represented by the following equation:

$$
R e=\frac{\text { Vair } * D_{\text {out }}}{\Upsilon_{\text {air }}}=1643.8
$$

where Vair is the approximate wind velocity in Bogotá and Yair is the kinematic viscosity of air. The latter should be calculated from the air's dynamic viscosity, as well as its density.

$$
\begin{array}{r}
\Upsilon_{\text {air }}=\frac{\text { viscosidad dinámica del aire }(\mu \text { air })}{\text { Densidad del aire }(\text { pair })} \\
=\frac{0,00001825 * \mathrm{~s} / \mathrm{m}^{2}}{1.2 \mathrm{~kg} / \mathrm{m}^{3}} \\
=1.52083 * 10^{-5} \mathrm{~m}^{2} / \mathrm{s}
\end{array}
$$

For Reynolds numbers comprised between 0.1 and 1000, the Nusselt number is given by equation:

$$
N u=0.40+0.54 R e^{0.52}
$$

Given that $\mathrm{Re}=1643.8$, for $\mathrm{Re}$ numbers comprised between 1000 and 50,000, equation (29) is expressed as:

$$
N u=0.30 R e^{0.6}
$$

From the aforementioned, we have that $\mathrm{Nu}=25.51$; which is why the convection coefficient would be equal to:

$$
\begin{aligned}
& h_{w}=\frac{0.02 \mathrm{~W} / \mathrm{m} * \mathrm{~K}}{0.03 \mathrm{~m}} * 25.51 \\
& =17.004 \mathrm{~W} / \mathrm{m}^{2} * K
\end{aligned}
$$

Based on the aforementioned, the receiver's energy loses to the environment would be:

$$
\begin{gathered}
Q_{\text {loss }}=\operatorname{ArU}_{L}(\operatorname{Trm}-\mathrm{Tamb}) \\
=1.09 \mathrm{~W} \\
Q_{\text {out }}=Q_{\text {opt }}-Q_{\text {loss }}=708.9 \mathrm{~W}
\end{gathered}
$$

With the useful energy delivered, it is possible to calculate the system's instantaneous thermal efficiency:

$$
n_{\text {inst }}=\frac{Q_{\text {out }}}{A a I_{b}} * 100=48,5 \%
$$




\section{TECCIENCIA}

We expected an instantaneous efficiency comprised between the range of 40 to $60 \%$, according to $(2,3,4,5)$. The aforementioned proves that the solar dish concentrator is more efficient than the flat-type collectors.

\section{Prototype design}

The prototype design was carried out with SOLIDWORKS software, which contemplates the parabola and focus characteristics, as well as the dimensions adjusted to the estimated budget

\subsection{Structure and solar monitoring mechanisms}

The support has four support points; each support point has a piece to level the structure to the
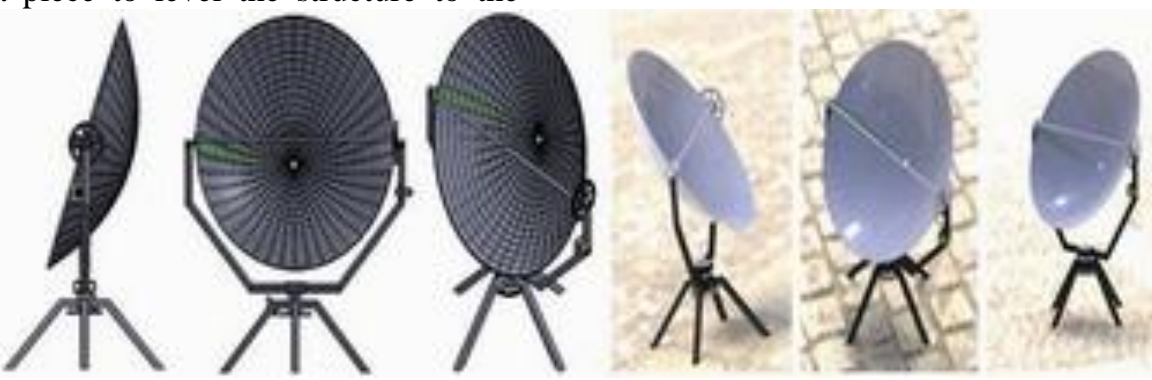

Figure 4: Design and rendering of the solar dish collector with solar monitor Table 7: Basic components of the parabolic solar dish concentrator

Table7. Basic components of the parabolic solar dish concentrator

\begin{tabular}{|c|c|}
\hline Component & Characteristics \\
\hline Concentractor dish & $\begin{array}{c}\text { The dish is made up of } 36 \text { polished stainless Steel parts, } \\
\text { reference } 430 \text { BA. }\end{array}$ \\
\hline Focus & $\begin{array}{c}\text { Cylinder } 3 \mathrm{~cm} \text { in diameter, which is located perpendicular to } \\
\text { the center of the dish }\end{array}$ \\
\hline Structure and solar monitoring mechanisms & $\begin{array}{c}\text { The support has four support points, each support point has a } \\
\text { piece to level the structure to the surface. } \\
\text { Pulley mechanisms with } 1: 15 \text { and 1:20 ratios are located on } \\
\text { the central axel of te structure and lateral to the dish, } \\
\text { respectively }\end{array}$ \\
\hline
\end{tabular}
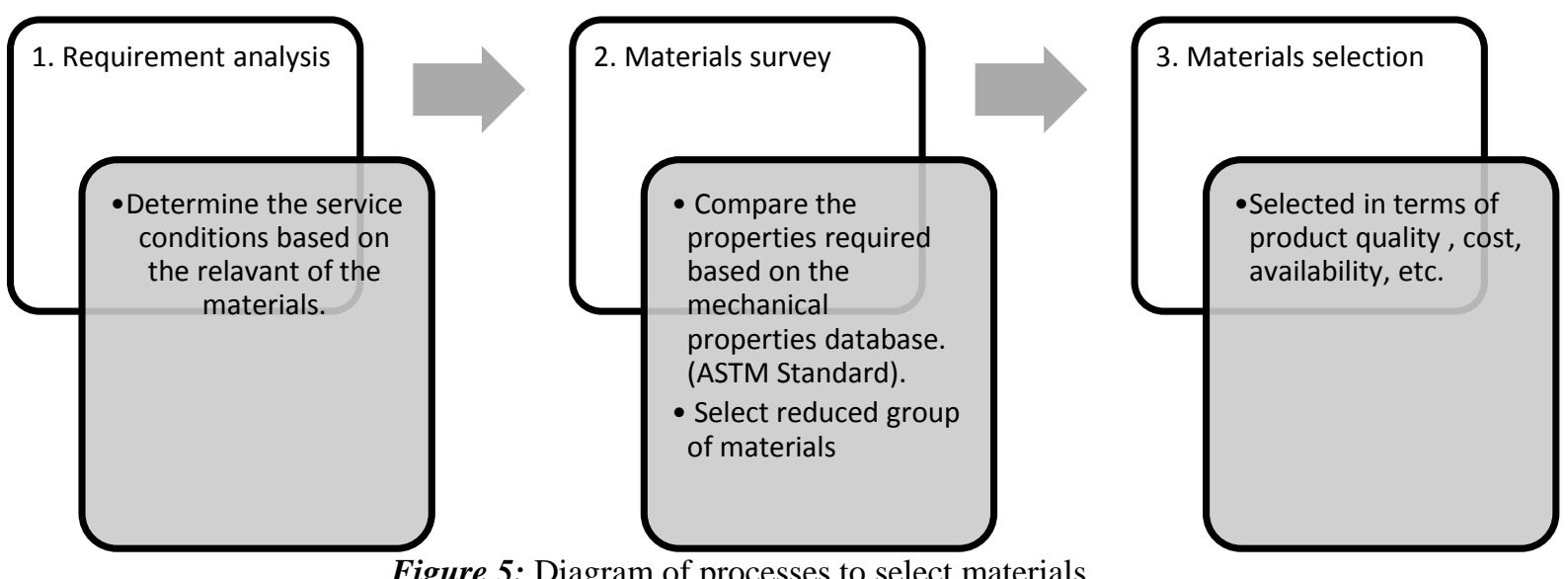

Figure 5: Diagram of processes to select materials

surface. Pulley mechanisms with 1:15 and 1:20 ratios are located on the central axle of the

\subsection{Selection of materials required to construct the collector}

To select the materials, the most relevant aspects and thermal factors. The collector's useful life, optical efficiency, and thermal efficiency depend Initially, we defined the optical, thermal, and other factors that must be considered to select the materials and, thereafter, we selected the material based on these criteria. 
Table 8: Requirements for the selection of the materials

\begin{tabular}{|c|c|c|c|}
\hline Requirement of the material & $\begin{array}{l}\text { Mechanical } \\
\text { Property }\end{array}$ & Desired Range & Materials \\
\hline $\begin{array}{c}\text { Must be shiny and reflect } \\
\text { suTnarbayles8o:nRtehqeufiroecmalents of } \\
\text { point. }\end{array}$ & Reflectivity & $\begin{array}{l}{[0.51-0.87][51-} \\
87 \%]\end{array}$ & $\begin{array}{l}\text { White PVC, high- reflectivity aluminum, } \\
\text { hard plate pre-painted white, galvanized } \\
\text { plate, painted plate, stainless steel. }\end{array}$ \\
\hline $\begin{array}{l}\text { Must withstand deformation and wear in the } \\
\text { presence of contact efforts by another harder }\end{array}$ & Hardness & {$[80-90] \% \mathrm{Hr}$} & $\begin{array}{c}\text { Steel 304,304L,310,314,316, } \\
\text { 316L,420,430. }\end{array}$ \\
\hline $\begin{array}{l}\text { Must be resistant to corrosion from the rain, } \\
\text { contact of metallic parts, among others. }\end{array}$ & Corrosion resistance & $\begin{array}{l}\text { Excellent } \\
\text { corrosion } \\
\text { resistance. }\end{array}$ & -AISI 304, AISI 316 \\
\hline Must be resistant to material rupture & $\begin{array}{l}\text { Resistant to } \\
\text { traction }\end{array}$ & $\begin{array}{c}{[45-70]} \\
(\mathrm{Kg} / \mathrm{mm} 2)\end{array}$ & $\begin{array}{l}\text { Steel } \\
\text { 304,304L,310,314,316, } \\
\text { 316L,420,430. }\end{array}$ \\
\hline $\begin{array}{l}\text { Resistance to high temperatures for welding } \\
\text { processes }\end{array}$ & $\begin{array}{l}\text { Resistant } \\
\text { to high } \\
\text { temperatures }\end{array}$ & {$\left[400-659^{\circ} \mathrm{C}\right]$} & $\begin{array}{l}\text { Steel } \\
\text { 304,304L,310,314,316, } \\
\text { 316L,420,430. }\end{array}$ \\
\hline $\begin{array}{l}\text { Capacity of materials to recover their shape } \\
\text { once the } \\
\text { force deforming them has disappeared }\end{array}$ & Elasticity & $\begin{array}{c}{[18-33] \mathrm{Rp} 0.2} \\
\%(\mathrm{Kg} / \mathrm{mm} 2 \\
\text { Min })\end{array}$ & $\begin{array}{c}\text { Steel } \\
\text { 304,304L,310,314,316, } \\
\text { 316L,420,430. }\end{array}$ \\
\hline
\end{tabular}

\subsection{Aspects evaluated to select the material}

For the conception of the materials to be used, we developed the diagram shown in Figure 5.

Note: Capacity of resistance to corrosion was classified according to the weight loss estimated during $24 \mathrm{~h}$ as: Excellent (below $25 \mathrm{mg} / \mathrm{dm} 2$ ), acceptable: (less than $250 \mathrm{mg} / \mathrm{dm} 2$ ), and poor (weight above $250 \mathrm{mg} / \mathrm{dm} 2$ ).

The most important material for proper functioning of the prototype is that used in the collector dish, given that the reflection of the rays will depend on it, which will be evident in the temperature increase of the focus. For this purpose, we analyzed the global reflectivity of some materials, according to the survey conducted.

Upon identifying the characteristics of the materials and conducting their survey, two different types of steels were selected: AISI 304 for the structure and AISI 430 for the dish, bearing in mind the following aspects and mechanical properties:

Availability, market cost, and maintenance: both materials selected are easily acquired in the market and have favorable costs. AISI 430T-BA, selected to construct the dish collector and AISI 304, selected to construct the structure.

Corrosion resistance: We kept in mind resistance to atmospheric corrosion, pitting corrosion, and inter- granular corrosion for the steel used in the collector because it will be exposed to rain, humidity, and high temperatures. The 430T-BA reference is a material resistant to a great variety of corrosive media, as well as to sulfurous gases. For the steel used on the structure, the 304 reference has excellent corrosion resistance in many environments; however, this aspect was not a determinant factor, given that it would undergo a paint coating after the welding process.

Resistance to $\mathrm{h}$ i $\mathrm{g}$ h temperatures and to welding: The AISI 430 dish material can withstand sun rays during a prolonged period of time and withstands temperatures up to $816{ }^{\circ} \mathrm{C}$, without losing its properties. The AISI 304 material withstands welding processes without losing its properties. The 430 reference is not suitable for welding processes, given the susceptibility for grain growth (martensite) during cooling, leading to loss of hardness. The dish material will not be exposed to welding processes, only cutting.

Resistance to oxidation: The $430 \mathrm{~T}$ reference withstands oxidation at temperatures to $810^{\circ} \mathrm{C}$ during continuous service and up to $870{ }^{\circ} \mathrm{C}$ for intermittent service.

Hardness: The AISI 304 and AISI 430 BA materials have high hardness; $88 \mathrm{Hr}$ (Rockwell) to $90 \mathrm{Hr}$, respectively.

Finish: The finish for the 430T BA material, used to manufacture the dish is characterized for being shiny for the purpose of it reflecting sun rays

\section{Prototype manufacture}

The structure comprises a base, an arc, a focal support, and a concentrator dish, as shown in Figure 6. Said structure has an approximate 68$\mathrm{kg}$ weight. 


\section{TECCIENCIA}

Figure 7 presents the diagram of processes for the

prototype's physical structure.

construction of the collector; Figure 8 shows the

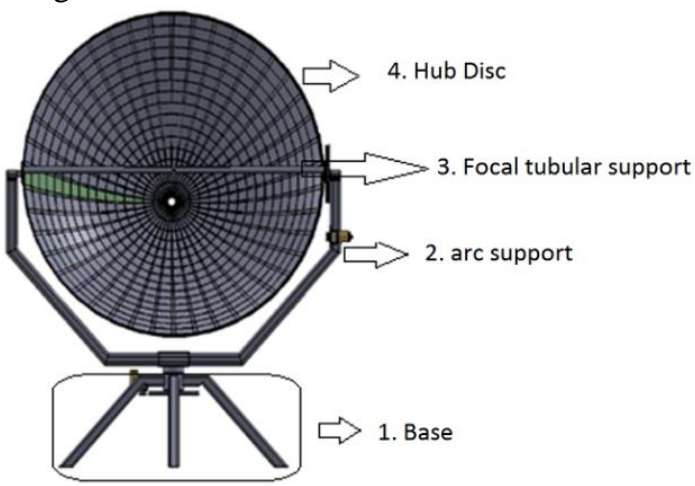

Figure 6: Parts of the solar collector

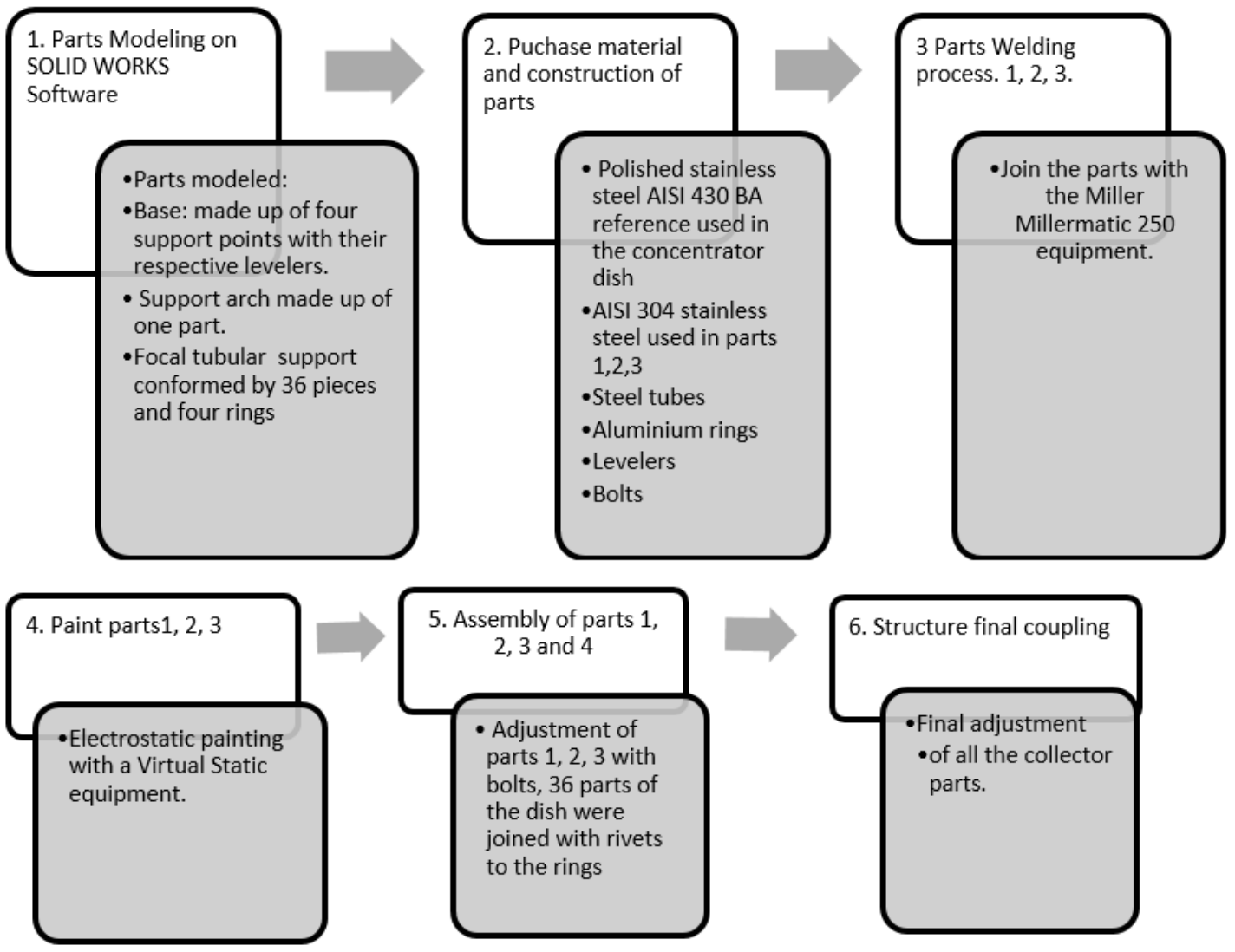

Figure 7: Diagram of processes to construct the solar collector

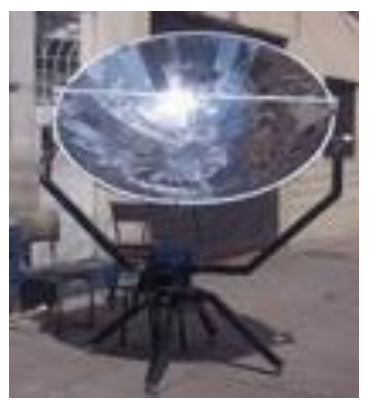

Figure 8: Physical structure of the prototype

\section{Conclusions}

The solar radiation atlas published by UPME is not sufficient when designing a system of solar radiation exploitation. Although this information is indicative and of consultation, upon dimensioning and designing a thermal conversion system, specific information is required on solar radiation in different sectors of Bogotá. 


\section{TECCIENCIA}

The optimal place to locate the prototype is la Guajira, given that the multi-annual mean availability of solar radiation is 2190 $\mathrm{kWh} / \mathrm{m}^{2} /$ year and the multiannual average of sunshine is 6-7 hours per day.

We suggest using AISI 430 material with polished finish to manufacture these types of collectors, considering that it is not possible to subject this material to industrial welding or cutting processes. We recommend using laser cut or water cut to maintain the properties of the steel and avoid oxidation and weight loss.

To continue with the research Project, we propose installing a Stirling motor to convert mechanical energy into electric energy. We propose as a future research project to investigate a hybrid between the photovoltaic and thermosolar technologies, given that the advantages of both technologies would be exploited and a more efficient prototype could be obtained.

\section{Acknowledgments}

This research would not have been possible without the contribution from Professor Alexander Alarcón, project director, as well as from the GCEM research group from Universidad Distrital Francisco José de Caldas.

\section{References}

[1] Unidad de planeación minero Energetica. UPME; Ministerio de Minas y Energía; Ministerio de ambiente y vivienda, «SIAC. Sistema de Información Ambiental de Colombia,» 2005. [En línea]. Available:

http://www.upme.gov.co/Docs/Atlas_Radiacion_Sol ar/1-Atlas_Radiacion_Solar.pdf. 